\title{
The Economics of Residential Solar Panels: A Comparison of Energy Charges for Different Load Profiles, Rate Plans, and Panel Orientations
}

\author{
John B. Broughton, Candace E. Ybarra, Prashanth U. Nyer* \\ Argyros School of Business \& Economics, Chapman University, Orange, CA, USA \\ Email: broughto@chapman.edu, cybarra@chapman.edu, *nyer@chapman.edu
}

How to cite this paper: Broughton, J. B., Ybarra, C. E., \& Nyer, P. U. (2022). The Economics of Residential Solar Panels: A Comparison of Energy Charges for Different Load Profiles, Rate Plans, and Panel Orientations. American Journal of Industrial and Business Management, 12, 180-194. https://doi.org/10.4236/ajibm.2022.122012

Received: January 21, 2022

Accepted: February 25, 2022

Published: February 28, 2022

Copyright $\odot 2022$ by author(s) and Scientific Research Publishing Inc. This work is licensed under the Creative Commons Attribution International License (CC BY 4.0).

http://creativecommons.org/licenses/by/4.0/

(c) (i) Open Access

\begin{abstract}
This paper examines the effect of different residential electrical load profiles (electrical energy consumption patterns within a day) on energy charges for customers with solar panels under different Southern California Edison time-of-use (TOU) rate plans. We identify the TOU plan which would be the most cost effective for solar customers with each load profile. The impact of the orientation of the solar panel array (whether it faces south or west or east) and shading patterns on electricity charges are examined. We also determine the ideal usage offset (the percentage of electricity consumption provided by the solar array) for the various scenarios presented in this paper. We perform these analyses using actual data for the average sized residential customer of Southern California Edison. While the data we examine are based on solar panel production estimates for southern California, the issues we address, and the methods we use, are applicable to virtually any locality. And our analysis reveals how myriad factors impact the economics of residential solar panel systems regardless of location.
\end{abstract}

\section{Keywords}

Solar Panels, Net Metering, Energy Load Profile, Time of Use, Savings, SCE, California, Orientation, Azimuth

\section{Introduction}

California continues to be at the forefront of the nation in proposing and enacting mandates that are designed to reduce future carbon emissions. On September 10, 2018, California Governor Jerry Brown issued executive order B-55-18 to 
achieve a statewide goal of carbon neutrality no later than 2045 (California Executive Order, 2018). The California Solar Mandate (California Legislative Information, 2019), which went into effect on January 1, 2020, requires new single-family and multi-family residential units up to three stories high to have solar panels that will generate the annual electrical energy needs of those buildings. At the time of this writing, the California Energy Commission is weighing the possibility of banning natural gas connections for new residential constructions or at least incentivizing builders to move away from natural gas and instead to rely more heavily on electric options for heating (Los Angeles Times, 2020). According to the data published by California Distributed Generation Statistics (https://www.californiadgstats.ca.gov/), there were over 4729 Mega Watts (MW) of new solar installations made in the state from 2017 to 2020, with the residential sector accounting for $3141 \mathrm{MW}$ of the above total, all of which has caused California to be ranked first in the nation for solar capacity (Solar Energy Industries Association, 2020). Ybarra, Broughton and Nyer (2021) provide a good overview of the trends in residential solar panel installations in the state.

California's major electric utility companies, which include Southern California Edison (SCE), Pacific Gas and Electric (PG\&E), and San Diego Gas \& Electric (SGGE), offer various time-of-use (TOU) rate plans, where the utility company charges different rates for energy consumption during different times of the day, different days of the week, and different seasons. As such, solar homeowners are faced with the task of choosing the best rate plan from among those that are offered. For example, should households in which no one is home during the workday choose the same rate plan as households in which at least some members are home during the normal workday? Would having members of the household that arrive home by mid-afternoon (such as school aged children) influence the choice? Would the orientation of the solar panels (whether they are mounted facing west, south or east) influence which rate plan is the most beneficial for the homeowner? And for each of these scenarios what is the ideal usage offset (how big should the solar panel array be relative to the electricity consumption) to maximize the long-term financial benefit for the homeowner? Finally, what is the impact of moderate levels of shading on the financial viability of residential solar panel installations? This paper provides solar homeowners and those planning on going solar with answers to these questions. And while we analyze data from Southern California, our results are easily generalizable to other regions and localities. This article is organized as follows: we begin by briefly describing our data sources including the load profiles that we use in this article, followed by our analyses where we identify the best solar panel orientation, and the best rate plans for each of the load profiles. We examine whether solar panels still make financial sense for SCE's residential customers, and then we determine the ideal usage offset (how much of the customer's annual electrical consumption should ideally be provided by solar panels.) Finally, we examine the effect of shading (shade cast on the solar panels from adjacent 
trees and structures) on the economic viability of solar panels.

\section{Data}

The solar production data for this study were obtained from the National Renewable Energy Laboratory (NREL), a national laboratory of the U.S. Department of Energy, via their PVWatts web application (https://pvwatts.nrel.gov/). While our focus is on the 92,867 area code in the city of Orange, California, we believe our analysis and findings are broadly applicable to all parts of southern California and more generally to other regions. The PVWatts site estimates the electricity production of a solar panel array based on a few simple inputs including the system's location, azimuth (the directional orientation of the array), tilt angle (relative to horizontal) and array size. PVWatts estimates the monthly electricity production of the system using the solar irradiance and meteorological data for the system's location. The data from PVWatts were corrected for daylight savings time.

The average annual electricity consumption per residential location in the 92,867 ZIP code area of Orange, California for 2018 and 2019 was $7411 \mathrm{kWh}$ (Southern California Edison, 2021a) and therefore we designed an unobstructed $4.541 \mathrm{~kW}$ DC solar panel system (with a roof angle of $20^{\circ}$, corresponding to a 4.5:12 roof pitch-a very common roof pitch in the warmer parts of southern California where there is no snow precipitation) that would generate $7411 \mathrm{kWh}$ annually when installed facing south. The same solar panel array if mounted on the west facing roof plane would generate $6611 \mathrm{kWh}$ of energy, if mounted facing east the panels would produce $6248 \mathrm{kWh}$, and if facing north would produce $5199 \mathrm{kWh}$.

Figure 1 depicts the annual solar energy production for such a solar panel array at various azimuth angles (North is $0^{\circ}$, East is $90^{\circ}$, South is $180^{\circ}$ and West is $270^{\circ}$ ). The maximum production at this location occurs when the solar panels are at a $191^{\circ}$ orientation, slightly west of true south. In the northern hemisphere, and especially farther away from the equator, solar panels are best mounted on the south and west roof planes. In this analysis we included the south, west and east facing installations in our calculations. By keeping constant the solar panel array size across all three azimuth orientations, we kept the customer's initial cost the same, and this made it possible for us to make meaningful comparisons of the annual electricity charges across the various scenarios.

Solar energy production is also affected by the tilt angle of the panels. Figure 2 depicts how the tilt angle (the angle of the array relative to the horizontal plane) affects the annual solar energy production. The maximum production occurs when the panel's tilt angle equals the latitude of the installation location ${ }^{1}$ This ZIP code area was chosen since its electricity consumption pattern closely matches the average for the interior portion of Orange County. Because electricity consumption in the interior exceeds that of more coastal areas, adoption of solar panels in the interior is likely to be more beneficial. For 2017-2020, homes in the coastal areas consumed an average of $5896 \mathrm{kWh}$ per year whereas homes in the interior areas (where summers are hotter) consumed $7379 \mathrm{kWh}$ per year. 


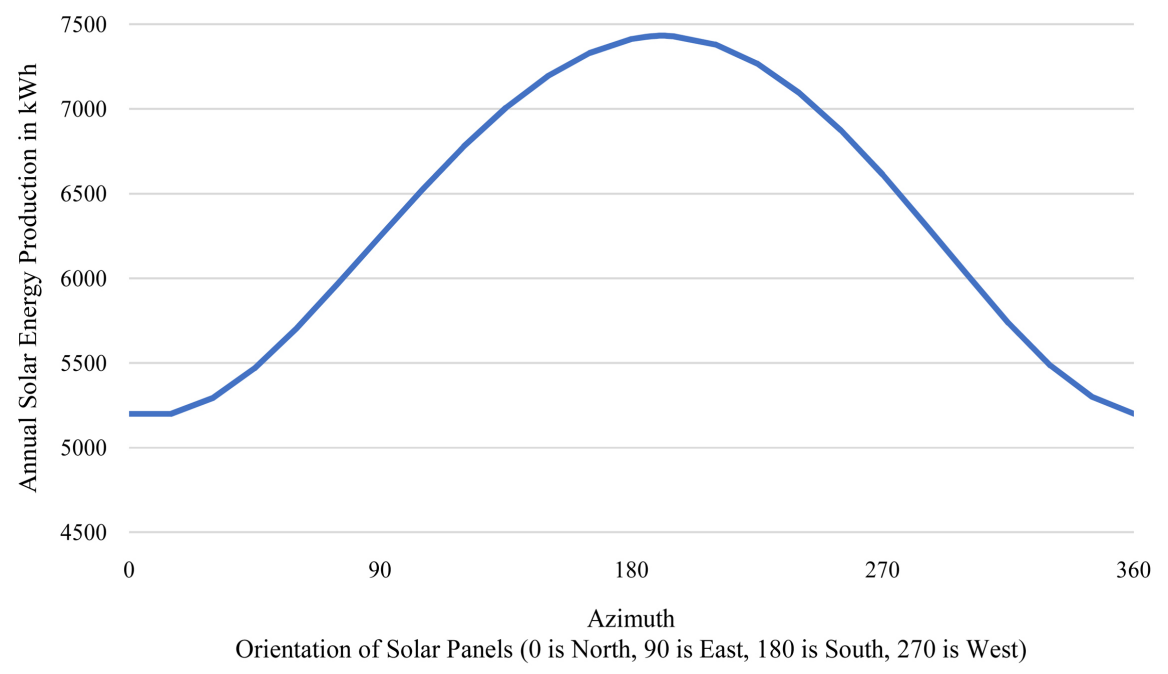

Figure 1. Annual solar energy production by panel orientation (4.541 kW DC array; tilt fixed at $20^{\circ}$ ).

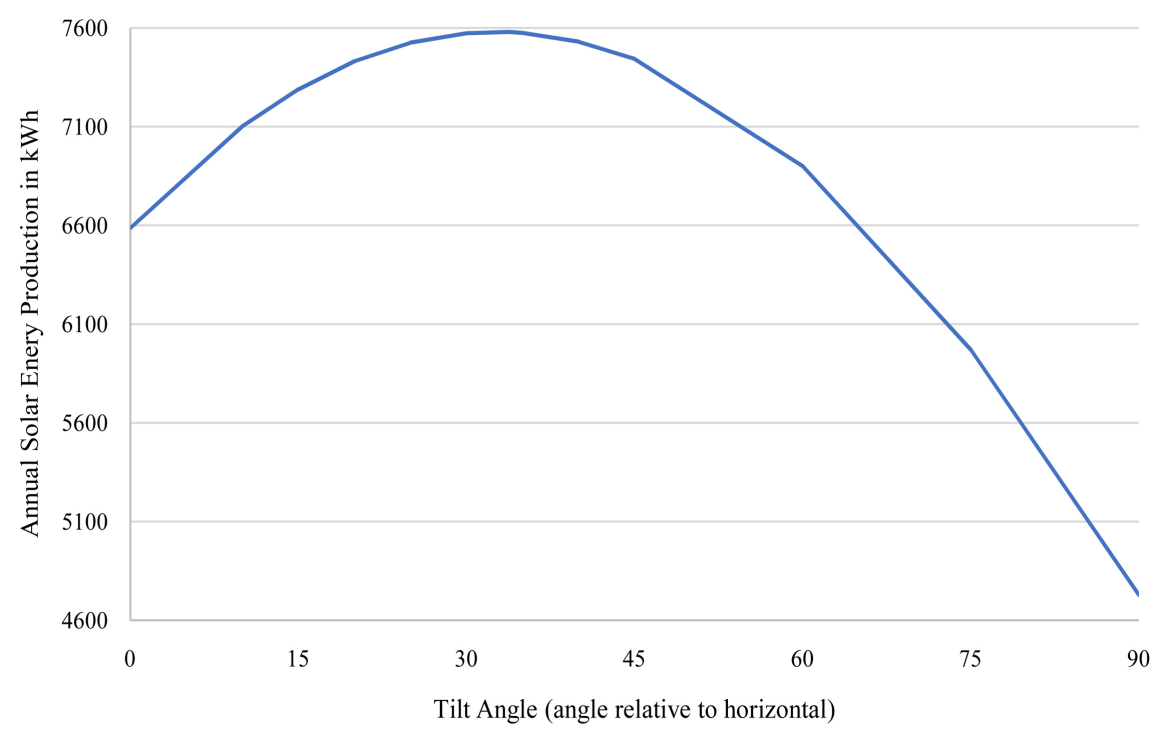

Figure 2. Annual solar energy production by panel tilt (4.541 kW DC array; azimuth fixed at $\left.191^{\circ}\right)$.

(approximately $33.5^{\circ}$ for Orange County, CA.) Since roof mounted solar panels are usually mounted flush with the surface of the roof (for structural and aesthetic reasons), they assume the same tilt angle as the roof and as such the home-owner will not have much leeway in selecting an optimal panel tilt angle. In our analysis we chose a tilt angle of $20^{\circ}$ since that is a common roof angle in southern California.

We used the four seasonal electricity consumption profiles (load profiles) first used by Broughton, Nyer and Ybarra (2021), who generated these load profiles examining the energy consumption patterns of several real households. The average electrical energy consumption for residential customers for each month of the year was obtained from Southern California Edison (2021a). In all the cases 
we assumed that the households used electricity for cooking.

The following description of the load profiles and the accompanying Figure 3 have been reproduced from Broughton, Nyer and Ybarra (2021) with permission.

1) Adults working from home. These households typically have someone home throughout the day. As such, during the summer months air-conditioners get turned on earlier in the afternoon. Once the residence is cooled, the electrical load will be relatively lower during the later evening hours.

2) Adults working outside the home with no children. These homes will typically be unoccupied during the work-day and will see a sharp increase in electricity use in the early evening hours in summer when the residents return from work.

3) Adults working from home but away from $5 \mathrm{PM}$ to $8 \mathrm{PM}$. These could be individuals who work from home and attend classes, run errands, go to the gym, etc. in the evening. These households typically have a usage pattern similar to load profile A with the difference that the energy consumption is lower between $5 \mathrm{PM}$ and $8 \mathrm{PM}$.

4) Adults working outside the home with school aged children. School aged children tend to be home for part of the summer, and when in school they tend to return home earlier than their parents. Thus, during the summer months these homes tend to see their air-conditioners turned on earlier than the homes without children (load profile B above).

Some of the simulated load profiles (for the summer months) are shown in Figure 3 (the load profile for working adults with school-aged children has not been included to improve the legibility of the illustration.) While our simulations divided the year into three seasons (Summer, Winter and Spring/Fall), Figure 3 includes only the Summer load profiles to declutter the illustration.

Forall load profiles the total electrical energy consumed during the year was

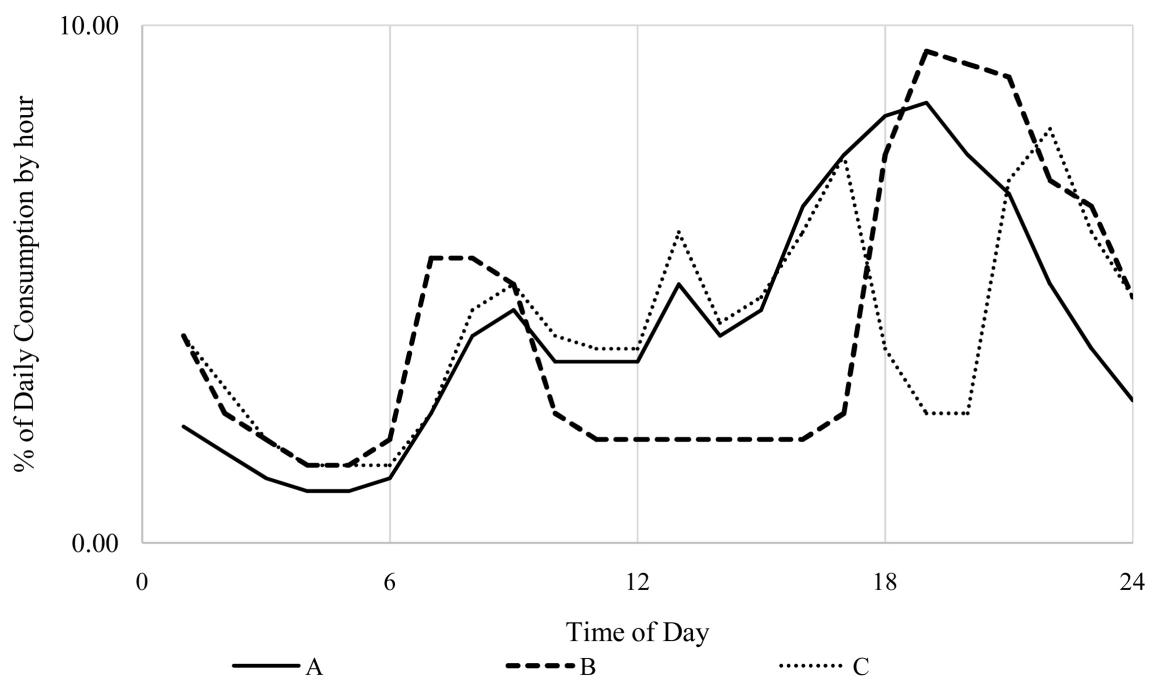

Figure 3. Load profiles. From Broughton, Nyer and Ybarra (2021). Used with permission. 
set to be $7411 \mathrm{kWh}$ (the average electrical consumption of the residential customers). While households where no one is home for several hours each work day will typically consume less electricity compared to a household where someone is home throughout the day, in this analysis we have chosen to make the electrical energy consumption the same for all household types since we are interested in examining how the energy charges are impacted by when during the day electricity is used. The load profiles we used are meant to be illustrative rather than exhaustive, and do not represent the energy consumption profiles of all households in the state.

We determined the cost of installing a $4.541 \mathrm{~kW}$ DC solar panel system by obtaining several quotes from licensed installers. After discarding outliers, the remaining quotes were clustered around an average of $\$ 14,846$ resulting in an after federal tax credit (presently $26 \%^{2}$ ) cost of $\$ 10,986$. To this we added the one-time $\$ 75$ interconnection fee that SCE is currently charging customers going solar. The cost of a similar sized solar panel installation will be higher if the panels are to be installed on a flat roof, or a roof made of terracotta tiles, or where the panels are spread over multiple roof planes. Finally, SCE's rate data for two of its TOU plans were obtained from SCE's web site (Southern California Edison, 2021b) and we used the rates levied during the 2020 calendar year.

\section{SCE's TOU Plans}

SCE currently has five TOU plans for residential customers. TOU-A and TOU-B are no longer available to new customers, but existing customers can continue on these plans for a maximum of five years or until July 31, 2022 whichever comes first. TOU-D Prime is available only to customers with electric vehicles or battery storage units, while the two remaining plans, TOU 4-9 and TOU 5-8, remain open to all customers. This analysis will only consider the two TOU rate plans that are currently available to all solar customers, TOU 4-9 and TOU 5-8. Table 1 summarizes the TOU rate plans included in this study. The TOU 4-9 plan has the highest rates from the 4:00 PM to 8:59 PM time period during the weekdays while the 5 - 8 plan has the highest rates on weekdays from 5:00 PM to 7:59 PM.

\section{Analysis and Findings}

We used the methodology and the processes used by Nyer, Broughton and Ybarra (2019) and Nyer, Ybarra and Broughton (2019) (which in turn were verified to match SCE's calculations) to determine the annual SCE bills for the various load profiles under both the TOU 4-9 and the TOU 5-8 rate plans, and for the south, west and east facing installations of the $4.541 \mathrm{~kW}$ DC solar panel array. Readers are encouraged to refer to the above referenced papers for more

${ }^{2}$ The federal tax credit was scheduled to decrease from $26 \%$ to $22 \%$ starting January 1 , 2021. However, towards the end of 2020 the $26 \%$ federal tax credit was extended for two additional years until the end of 2022 . 
Table 1. Major differences in the current SCE Tou plans (the approximate price per kWh effective June 2020 has been included for illustration).

\begin{tabular}{|c|c|c|}
\hline & TOU 4-9 & TOU 5-8 \\
\hline & \multicolumn{2}{|c|}{ Summer Weekdays (June through September) } \\
\hline On Peak & $\begin{array}{c}4 \mathrm{pm}-9 \mathrm{pm} \\
(\$ 0.41)\end{array}$ & $\begin{array}{c}5 \mathrm{pm}-8 \mathrm{pm} \\
(\$ 0.52)\end{array}$ \\
\hline \multirow[t]{2}{*}{ Off Peak } & $\begin{array}{c}9 \mathrm{pm}-4 \mathrm{pm} \\
(\$ 0.26)\end{array}$ & $\begin{array}{c}8 \mathrm{pm}-5 \mathrm{pm} \\
(\$ 0.26)\end{array}$ \\
\hline & \multicolumn{2}{|c|}{ Summer Weekends \& Holidays (June through September) } \\
\hline Mid Peak & $\begin{array}{c}4 \mathrm{pm}-9 \mathrm{pm} \\
(\$ 0.34)\end{array}$ & $\begin{array}{c}5 \mathrm{pm}-8 \mathrm{pm} \\
(\$ 0.39)\end{array}$ \\
\hline \multirow[t]{2}{*}{ Off Peak } & $\begin{array}{c}9 \mathrm{pm}-4 \mathrm{pm} \\
(\$ 0.26)\end{array}$ & $\begin{array}{c}8 \mathrm{pm}-5 \mathrm{pm} \\
(\$ 0.26)\end{array}$ \\
\hline & \multicolumn{2}{|c|}{ Winter Weekdays (October through May) } \\
\hline Mid Peak & $\begin{array}{c}4 \mathrm{pm}-9 \mathrm{pm} \\
(\$ 0.36)\end{array}$ & $\begin{array}{c}5 \mathrm{pm}-8 \mathrm{pm} \\
(\$ 0.42)\end{array}$ \\
\hline Off Peak & $\begin{array}{c}9 \mathrm{pm}-8 \mathrm{am} \\
(\$ 0.27)\end{array}$ & $\begin{array}{c}8 \mathrm{pm}-8 \mathrm{am} \\
(\$ 0.28)\end{array}$ \\
\hline \multirow[t]{2}{*}{ Super Off Peak } & $\begin{array}{c}8 \mathrm{am}-4 \mathrm{pm} \\
(\$ 0.25)\end{array}$ & $\begin{array}{c}8 \mathrm{am}-5 \mathrm{pm} \\
(\$ 0.24)\end{array}$ \\
\hline & \multicolumn{2}{|c|}{ Winter Weekends \& Holidays (October through May) } \\
\hline Mid Peak & $\begin{array}{c}4 \mathrm{pm}-9 \mathrm{pm} \\
(\$ 0.36)\end{array}$ & $\begin{array}{c}5 \mathrm{pm}-8 \mathrm{pm} \\
(\$ 0.42)\end{array}$ \\
\hline Off Peak & $\begin{array}{c}9 \mathrm{pm}-8 \mathrm{am} \\
(\$ 0.27)\end{array}$ & $\begin{array}{c}8 \mathrm{pm}-8 \mathrm{am} \\
(\$ 0.28)\end{array}$ \\
\hline Super Off Peak & $\begin{array}{c}8 \mathrm{am}-4 \mathrm{pm} \\
(\$ 0.25)\end{array}$ & $\begin{array}{c}8 \mathrm{am}-5 \mathrm{pm} \\
(\$ 0.24)\end{array}$ \\
\hline $\begin{array}{l}\text { Baseline Credit (per } \\
\text { kWh upto baseline } \\
\text { allocation) }\end{array}$ & $\$ 0.08$ & $\$ 0.08$ \\
\hline Daily basic charge & $\$ 0.03$ & $\$ 0.03$ \\
\hline Daily minimum charge & $\$ 0.35$ & $\$ 0.35$ \\
\hline
\end{tabular}

Source: Southern California Edison.

details on how the annual energy charges were calculated. While the output of solar panels decreases slightly with age (they are usually guaranteed to produce at least $80 \%$ of their brand new output even after 25 years) we have not included that in our modeling. The reasoning is that while avoided costs decline as energy output declines, avoided costs increase along with increasing rates charged by utility companies such as SCE whose residential rates increased by $18 \%$ in the ten years between 2009 and 2019. 


\subsection{The Best Solar Panel Orientation}

The annual electricity charges for the various load profiles are shown in Table 2. What is evident is that all the load profiles included in this analysis incurred a lower annual electricity bill when the panels were mounted on a south-facing roof plane. While this might seem to be an obvious conclusion (since south facing arrays generate more solar energy), this finding runs contrary to the recommendations of some solar installers who claim that west facing panels will result in lower annual electricity bills under the TOU rate plans. This is clearly not true for the load profiles examined in this paper. We discuss this further later in this paper.

\subsection{The Best Rate Plan}

We also found that in most scenarios examined in this paper, the TOU 4-9 resulted in lower annual electricity charges for a given solar panel array size (see

Table 2. Annual SCE electricity charge, $\mathrm{IRR}^{3}, \mathrm{MIRR}^{4}$ and payback period by load profile, rate plan and solar panel orientation. (using a $4.541 \mathrm{~kW}$ DC solar panel array for all azimuth orientations.

\begin{tabular}{|c|c|c|c|c|c|c|c|c|c|}
\hline \multicolumn{2}{|c|}{ Panel orientation } & \multicolumn{2}{|c|}{ South Facing Panels } & \multicolumn{2}{|c|}{ West Facing Panels } & \multicolumn{2}{|c|}{ East Facing Panels } & \multicolumn{2}{|c|}{ No Solar Panels } \\
\hline \multicolumn{2}{|c|}{ Annual solar production } & \multicolumn{2}{|c|}{$7411 \mathrm{kWh}$} & \multicolumn{2}{|c|}{$6611 \mathrm{kWh}$} & \multicolumn{2}{|c|}{$6248 \mathrm{kWh}$} & \multicolumn{2}{|c|}{$0 \mathrm{kWh}$} \\
\hline \multicolumn{2}{|c|}{ Annual electricity consumption } & \multicolumn{2}{|c|}{$7411 \mathrm{kWh}$} & \multicolumn{2}{|c|}{$7411 \mathrm{kWh}$} & \multicolumn{2}{|c|}{$7411 \mathrm{kWh}$} & \multicolumn{2}{|c|}{$7411 \mathrm{kWh}$} \\
\hline \multicolumn{2}{|c|}{ Usage Offset } & \multicolumn{2}{|c|}{$100.0 \%$} & \multicolumn{2}{|c|}{$89.2 \%$} & \multicolumn{2}{|c|}{$84.3 \%$} & \multicolumn{2}{|c|}{-} \\
\hline \multirow{3}{*}{\multicolumn{2}{|c|}{ SCE Rate Plans }} & TOU & TOU & TOU & TOU & TOU & TOU & TOU & TOU \\
\hline & & $4-9$ & $5-8$ & $4-9$ & $5-8$ & $4-9$ & $5-8$ & $4-9$ & $5-8$ \\
\hline & & Plan & Plan & Plan & Plan & Plan & Plan & Plan & Plan \\
\hline \multirow{4}{*}{$\begin{array}{l}\text { A. Working from } \\
\text { home (WFH) }\end{array}$} & Annual charge & $\$ 389.21$ & $\$ 445.29$ & $\$ 456.13$ & $\$ 506.77$ & $\$ 612.56$ & $\$ 664.25$ & \multirow{4}{*}{$\$ 1889$} & \multirow{4}{*}{$\$ 1997$} \\
\hline & IRR & $12.91 \%$ & $12.34 \%$ & $12.23 \%$ & $11.71 \%$ & $10.61 \%$ & $10.07 \%$ & & \\
\hline & MIRR & $8.36 \%$ & $8.19 \%$ & $8.16 \%$ & $8.00 \%$ & $7.66 \%$ & $7.48 \%$ & & \\
\hline & Payback period & $7.38 \mathrm{yrs}$ & 7.66 yrs & $7.72 \mathrm{yrs}$ & 8.00 yrs & 8.67 yrs & 9.03 yrs & & \\
\hline \multirow{4}{*}{$\begin{array}{l}\text { B. Working } \\
\text { adults with no } \\
\text { school-aged } \\
\text { children }\end{array}$} & Annual charge & $\$ 444.60$ & $\$ 513.32$ & $\$ 509.65$ & $\$ 576.55$ & $\$ 662.41$ & $\$ 726.54$ & \multirow{4}{*}{$\$ 1919$} & \multirow{4}{*}{$\$ 2041$} \\
\hline & IRR & $12.65 \%$ & $11.95 \%$ & $11.99 \%$ & $11.30 \%$ & $10.40 \%$ & $9.72 \%$ & & \\
\hline & MIRR & $8.28 \%$ & $8.08 \%$ & $8.09 \%$ & $7.88 \%$ & $7.59 \%$ & $7.37 \%$ & & \\
\hline & Payback period & $7.50 \mathrm{yrs}$ & $7.87 \mathrm{yrs}$ & $7.85 \mathrm{yrs}$ & $8.24 \mathrm{yrs}$ & $8.80 \mathrm{yrs}$ & $9.28 \mathrm{yrs}$ & & \\
\hline \multirow{4}{*}{$\begin{array}{l}\text { C. WFH with } \\
\text { outside evening } \\
\text { activities }\end{array}$} & Annual charge & $\$ 304.01$ & $\$ 268.56$ & $\$ 376.00$ & $\$ 330.53$ & $\$ 525.04$ & $\$ 487.33$ & \multirow{4}{*}{$\$ 1803$} & \multirow{4}{*}{$\$ 1818$} \\
\hline & IRR & $12.90 \%$ & $13.26 \%$ & $12.18 \%$ & $12.64 \%$ & $10.63 \%$ & $11.03 \%$ & & \\
\hline & MIRR & $8.36 \%$ & $8.46 \%$ & $8.14 \%$ & $8.28 \%$ & $7.67 \%$ & $7.79 \%$ & & \\
\hline & Payback period & $7.38 \mathrm{yrs}$ & $7.21 \mathrm{yrs}$ & 7.75 yrs & $7.51 \mathrm{yrs}$ & 8.65 yrs & 8.40 yrs & & \\
\hline \multirow{4}{*}{$\begin{array}{l}\text { D. Working } \\
\text { adults with } \\
\text { school-aged } \\
\text { children }\end{array}$} & Annual charge & $\$ 422.80$ & $\$ 473.10$ & $\$ 489.69$ & $\$ 535.10$ & $\$ 642.95$ & $\$ 688.11$ & \multirow{4}{*}{$\$ 1908$} & \multirow{4}{*}{$\$ 2010$} \\
\hline & IRR & $12.76 \%$ & $12.25 \%$ & $12.08 \%$ & $11.61 \%$ & $10.49 \%$ & $10.01 \%$ & & \\
\hline & MIRR & $8.31 \%$ & $8.17 \%$ & $8.12 \%$ & $7.97 \%$ & $7.62 \%$ & $7.47 \%$ & & \\
\hline & Payback period & 7.45 yrs & $7.71 \mathrm{yrs}$ & 7.80 yrs & 8.06 yrs & 8.75 yrs & 9.07 yrs & & \\
\hline
\end{tabular}

${ }^{3}$ In determining the IRR and MIRR, the annual avoided cost was calculated by subtracting the annual SCE bill amount for each load profile from the lower of the two annual SCE bills for the No Solar Panel scenario for that load profile.

${ }^{4}$ The MIRR calculation assumes a $6 \%$ reinvestment rate. 
Table 2). Solar panels (especially west-facing panels) typically produce a lot of energy during the 4 PM hour when these homes are not consuming much electricity. This excess solar energy is sold to the grid at the peak rate under the TOU 4-9 plan. Homes under the TOU 5-8 plan will be selling energy to the grid during the 4 PM hour at a significantly lower rate (since under the 5-8 plan the peak rate starts at $5 \mathrm{PM}$ ). The exception to this is load profile $\mathrm{C}$ where the electricity consumption is low between $5 \mathrm{PM}$ and $8 \mathrm{PM}$, which results in the customers incurring lower annual electricity charges under the TOU 5-8 plan. These findings are somewhat contrary to the findings of Nyer, Ybarra and Broughton (2019) who determined that the TOU 5-8 plan was slightly less expensive compared to the TOU 4-9 plan for the one customer whose energy consumption they analyzed. A likely explanation for this discrepancy is that the SCE rates for the TOU 5-8 plan (relative to the TOU 4-9 plan) have increased since 2019. For example, the on-peak summer rate for the TOU 5-8 plan increased from $\$ 0.49$ per kWh in August 2019 to $\$ 0.52$ per $\mathrm{kWh}$ in June 2020, while the on-peak summer rate for the TOU 4-9 plan remained unchanged at $\$ 0.41$ per kWh. Thus, the TOU 5-8 plan has become considerably less attractive to customers.

\subsection{Are Solar Panels Still a Good Investment?}

While solar panel systems are expected to last well beyond the typical warranty of 25 years, we chose to be conservative and to calculate the internal rate of return (IRR), the modified internal rate of return (MIRR) and the payback periods using the avoided costs for just twenty-five years. The IRR is the discount rate that results in the present value of the cash flows (the avoided costs) equaling the initial investment. It may be interpreted as the expected return on the investment, assuming that cash flows received over the life of the investment can be reinvested to earn the IRR. For investments with attractive IRRs, this reinvestment assumption is generally considered overly optimistic. The MIRR is an alternative measure of expected return that assumes more realistically that cash flows can be reinvested to earn the investor's opportunity cost of capital. The opportunity cost of capital is the rate of return available on alternative investments with a risk profile similar to the investment being considered. It may also be thought of as the market determined cost of financing the investment. In the case of a solar panel system, the upfront cost is certain, and the level and timing of cash flows over the life of the system are substantially assured. Thus, it is reasonable to assume that investment in a solar panel system has low risk and a correspondingly low opportunity cost of capital. Furthermore, at the time of this writing, an informal survey of solar system providers indicated that the cost to finance a system is in the range of $3 \%-5 \%$. The payback period of an investment is the amount of time needed to recover the initial cost of the investment. In general, investments with short payback periods are preferred over those with long payback periods. The expected payback period is commonly cited by com- 
panies in marketing solar panel systems. The investment decision rule for IRR and MIRR is to accept projects, in this case solar panel investments, if the performance measure (IRR or MIRR) exceeds the opportunity cost of capital. There is no clear-cut decision rule for payback period other than shorter is better than longer.

Table 2 reports the IRR, MIRR, and payback period for all the scenarios examined in this paper. All combinations of load profile, TOU, and panel orientation result in IRRs in excess of $11.5 \%$, with the south facing installations yielding the highest IRRs in the $14 \%-15 \%$ range. In computing MIRRs, we assumed a reinvestment rate of $6 \%$. Table 2 indicates that virtually all MIRRs exceeded $8 \%$, well in excess of the assumed opportunity cost of capital (reinvestment rate) of $6 \%$. We also computed MIRRs assuming a range of reinvestment rates from zero to $20 \%$. MIRR exceeds opportunity cost of capital for any opportunity cost up to the IRR. Thus, solar panels continue to be a good investment for customers, especially those in California. California residential customers pay some of the highest electricity rates in the United States ( $\$ 0.21$ per kWh average retail price in August 2020, Statista, 2020), which translates into higher avoided costs that can be achieved by installing solar panels.

\subsection{Ideal Usage Offset}

As described earlier, the usage offset of a solar panel installation is the annual electrical energy generated by the solar panels expressed as a percentage of the annual electrical energy consumed by the household. The ideal usage offset is the usage offset that maximizes the net present value (NPV) of the solar panel installation. NPV is the discounted present value of the avoided costs over the twenty-five year warranted life of the panels less the cost of the solar panel installation net of the federal tax credit. A discount rate of $6 \%$ per year was assumed. (These calculations were repeated with discount rates of $4 \%$ and $8 \%$ with similar findings.) To do this calculation, we scaled the solar panel installation in $1 \%$ increments between $90 \%$ and $160 \%$ of the size of the original installation. We assumed that the production and prices scaled linearly. In this analysis where we examine different load profiles and different solar panel orientations, we determine that the answer to the question "What is the ideal usage offset?" is somewhat complicated. See Table 3 for a summary of our findings.

The ideal usage offset mostly ranged from $104 \%$ to $129 \%$ with the ideal usage offset being slightly higher for the TOU 5-8 plan. For the unusual load profile C, energy usage was assumed to be very low during the 5 PM to 8 PM hours (when electricity rates are very high on both TOU plans) resulting in energy being purchased from SCE mostly during the lower rate periods and hence resulting in a lower ideal usage offset.

It is clear from Table 3 (and as discussed previously) that south-facing installations are financially preferable for the homeowner, with south-facing solar panel arrays providing a higher NPV compared to west-facing or east-facing 
Table 3. Maximum NPV 5 , Ideal usage offset and array size by load profile, rate plan and solar panel orientation (using an array size that maximizes the NPV for that scenario; NPV rounded to the nearest Dollar; Ideal usage offset ${ }^{6}$ shown as a percentage).

\begin{tabular}{|c|c|c|c|c|c|c|c|}
\hline \multicolumn{2}{|c|}{ Panel orientation } & \multicolumn{2}{|c|}{ South Facing Panels } & \multicolumn{2}{|c|}{ West Facing Panels } & \multicolumn{2}{|c|}{ East Facing Panels } \\
\hline \multicolumn{2}{|c|}{ Annual electricity consumption } & \multicolumn{2}{|c|}{$7411 \mathrm{kWh}$} & \multicolumn{2}{|c|}{$7411 \mathrm{kWh}$} & \multicolumn{2}{|c|}{$7411 \mathrm{kWh}$} \\
\hline & SCE Rate Plans & $\begin{array}{c}\text { TOU } \\
4 \text { - } 9 \text { Plan }\end{array}$ & $\begin{array}{c}\text { TOU } \\
5 \text { - } 8 \text { Plan }\end{array}$ & $\begin{array}{c}\text { TOU } \\
4 \text { - } 9 \text { Plan }\end{array}$ & $\begin{array}{c}\text { TOU } \\
5 \text { - } 8 \text { Plan }\end{array}$ & $\begin{array}{c}\text { TOU } \\
4 \text { - } 9 \text { Plan }\end{array}$ & $\begin{array}{c}\text { TOU } \\
5 \text { - } 8 \text { Plan }\end{array}$ \\
\hline \multirow{4}{*}{$\begin{array}{l}\text { A. Working from } \\
\text { home }\end{array}$} & Max NPV & $\$ 8642$ & $\$ 8241$ & $\$ 8120$ & $\$ 7774$ & $\$ 6049$ & $\$ 5740$ \\
\hline & Ideal Usage & $123 \%$ & $126 \%$ & $115 \%$ & $118 \%$ & $126 \%$ & $128 \%$ \\
\hline & Offset & $5.59 \mathrm{~kW}$ & $5.72 \mathrm{~kW}$ & $5.86 \mathrm{~kW}$ & $5.99 \mathrm{~kW}$ & $6.81 \mathrm{~kW}$ & $6.90 \mathrm{~kW}$ \\
\hline & Ideal Array Size & DC & DC & DC & DC & DC & DC \\
\hline \multirow{4}{*}{$\begin{array}{l}\text { B. Working adults } \\
\text { with no school-aged } \\
\text { children }\end{array}$} & Max NPV & $\$ 8555$ & $\$ 7996$ & $\$ 7916$ & $\$ 7554$ & $\$ 5910$ & $\$ 5492$ \\
\hline & Ideal Usage & $125 \%$ & $129 \%$ & $118 \%$ & $120 \%$ & $129 \%$ & $131 \%$ \\
\hline & Offset & $5.68 \mathrm{~kW}$ & $5.86 \mathrm{~kW}$ & $5.99 \mathrm{~kW}$ & $6.13 \mathrm{~kW}$ & $6.95 \mathrm{~kW}$ & $7.08 \mathrm{~kW}$ \\
\hline & Ideal Array Size & DC & DC & DC & DC & DC & DC \\
\hline \multirow{4}{*}{$\begin{array}{l}\text { C. WFH with outside } \\
\text { evening activities }\end{array}$} & Max NPV & $\$ 8404$ & $\$ 8684$ & $\$ 7613$ & $\$ 8021$ & $\$ 5900$ & $\$ 6364$ \\
\hline & Ideal Usage & $115 \%$ & $111 \%$ & $109 \%$ & $104 \%$ & $119 \%$ & $114 \%$ \\
\hline & Offset & $5.22 \mathrm{~kW}$ & $5.04 \mathrm{~kW}$ & $5.54 \mathrm{~kW}$ & $5.31 \mathrm{~kW}$ & $6.40 \mathrm{~kW}$ & $6.13 \mathrm{~kW}$ \\
\hline & Ideal Array Size & DC & DC & DC & DC & DC & DC \\
\hline \multirow{4}{*}{$\begin{array}{l}\text { D. Working adults } \\
\text { with school-aged } \\
\text { children }\end{array}$} & Max NPV & $\$ 8654$ & $\$ 8200$ & $\$ 7992$ & $\$ 7712$ & $\$ 5389$ & $\$ 5747$ \\
\hline & Ideal Usage & $124 \%$ & $127 \%$ & $117 \%$ & $119 \%$ & $124 \%$ & $129 \%$ \\
\hline & Offset & $5.63 \mathrm{~kW}$ & $5.77 \mathrm{~kW}$ & $5.95 \mathrm{~kW}$ & $6.04 \mathrm{~kW}$ & $6.68 \mathrm{~kW}$ & $6.95 \mathrm{~kW}$ \\
\hline & Ideal Array Size & DC & DC & DC & DC & DC & DC \\
\hline
\end{tabular}

arrays. A closer look at the ideal usage offsets levels in Table 3 indicates that the ideal usage offsets for west-facing installations are lower than for south-facing installations. This is likely to be the source of the incorrect recommendation made by some solar panel installers that west-facing solar panels are a better value under the TOU plans. To understand this let us look at an example from Table 3. The ideal usage offset for load profile A with south-facing panels under the TOU 4-9 plan is $123 \%$ compared to the $115 \%$ for this customer had the panels been mounted facing west. However, this does not imply that the west-facing solar panel installation can be smaller than (and therefore less expensive than) the south-facing panel array. As Table 3 indicates, the array size that maximizes the NPV for the south-facing panels is $5.59 \mathrm{~kW}$ DC compared to the $5.86 \mathrm{~kW}$ DC array needed to maximize NPV for west-facing panels. Thus, the west-facing array would have to be $5 \%$ larger (and thus more expensive) resulting in a lower NPV for the west-facing array.

It should be noted that homeowners going solar will ordinarily be unable to

${ }^{5}$ The Net Present Value (NPV) is the discounted present value of the avoided costs over twenty-five years less the cost of the solar panels net of the federal tax credit. A discount rate of $6 \%$ per year was assumed. The Maximum NPV is the NPV resulting from an array size that maximizes the NPV for the given scenario.

${ }^{6}$ The ideal usage offset is the ratio of solar energy production to energy consumption that results in the maximum NPV for that usage scenario. The percentages have been rounded to the nearest integer. 
achieve a precise target usage offset level since the production capacity of solar panel arrays takes the form of a stepped function with each additional panel contributing several percentage points to the usage offset. This will become clearer with an illustration. The solar installation discussed earlier in this paper was a $4.541 \mathrm{~kW}$ DC system consisting of 13 LG $349 \mathrm{~W}$ panels that generated 7411 $\mathrm{kWh}$ when mounted facing south at a $20^{\circ}$ tilt. With the customer consuming $7411 \mathrm{kWh}$ of electrical energy each year this resulted in a 100\% usage offset. If the customer had installed one more solar panel, the generation would have increased by one thirteenth (to $7981 \mathrm{kWh}$ ) and the usage offset would have increased from $100 \%$ to $107.7 \%$ leaving the customer unable to achieve a usage offset level in between $100 \%$ and $107.7 \%$ (without changing their consumption). In addition, the energy production of an array will vary from year to year based on climatic conditions, and the energy consumption of a household is also likely to vary from year to year. All of this makes it difficult for a solar customer to achieve a predetermined usage offset level. Therefore, for most practical purposes homeowners looking to install solar panels should attempt to size their system to achieve a usage offset level close to that which maximizes their NPV.

\subsection{Effects of Shading}

In the preceding analyses we used solar panel arrays that were unobstructed by any shade from trees or buildings (the PVWatts data account for seasonal cloud patterns, fog etc.) Would solar panels continue to be financially viable with some shade? Every solar panel installation is unique in terms of the structures and vegetation around it, so in the interest of generalization, we chose to model two additional scenarios where the solar panel installation had shade causing structures in all directions extending from the horizon up to an elevation (angle relative to the horizontal measured from the center of the solar panel array) of $15^{\circ}$ and $30^{\circ}$. Industry experts estimate that shade causes the solar panel output to be cut in half EnergySage (2017). We used data from the University of Oregon, Solar Radiation Monitoring Laboratory (2019) to model the position of the sun at various times of the day, and various months of the year (see Figure 4). We performed an analysis where we reduced the solar panel output by $50 \%$ when the sun fell below the shade elevation. The sun path data were corrected for daylight savings time. Table 4 shows the impact of shading on the solar energy generation potential of a $4.541 \mathrm{~kW} \mathrm{DC}$ array with no shading (shading elevation $0^{\circ}$ ) and shading up to elevations of $15^{\circ}$ and $30^{\circ}$. For every load profile, panel orientation, rate plan, and shading elevation angle combination we calculated the maximum NPV for that scenario by scaling the installation size in one percent increments from $90 \%$ to $160 \%$ of the original $4.541 \mathrm{~kW} \mathrm{DC}$ array size. The results are shown in Table 5 where we report the maximum NPVs of installations without shading, and with shading up to $15^{\circ}$ and $30^{\circ}$ elevation. In each case we use the usage offset that maximizes NPV for that scenario. As expected, the NPV drops when shading increases; however even with shading at $30^{\circ}$ elevation in all 


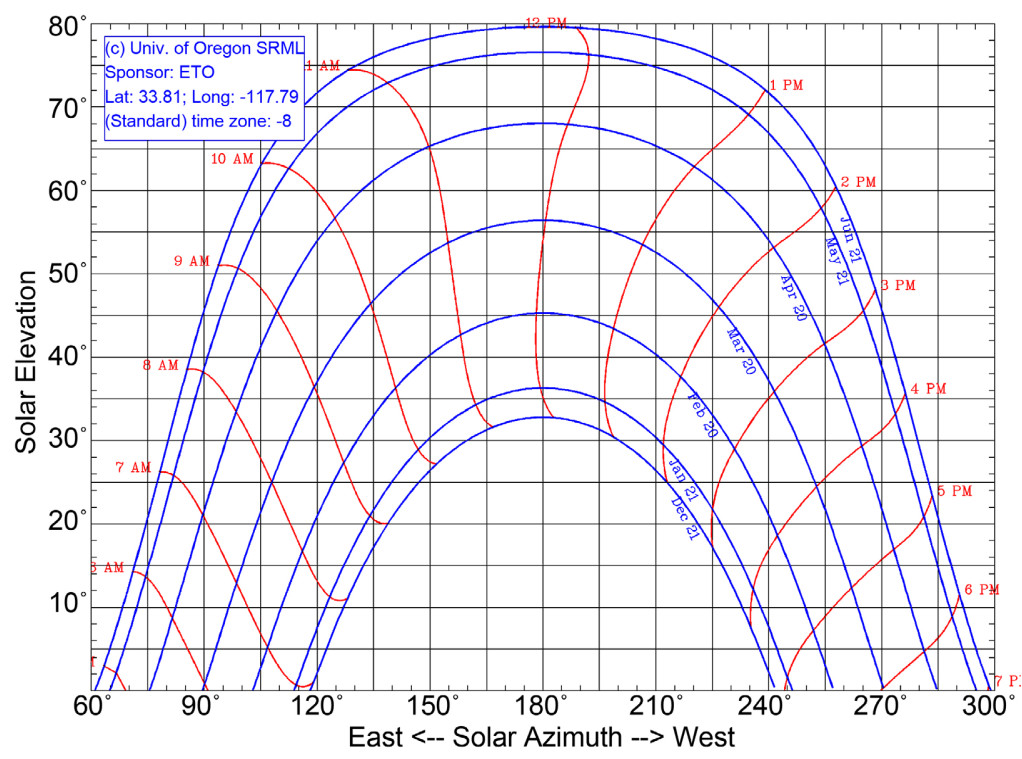

Figure 4. Sun path plot for orange, California ( University of Oregon, SRML.

Table 4. Solar energy output of a $4.514 \mathrm{~kW} \mathrm{DC}$ solar panel array with different orientations and shading Up To $0^{\circ}, 15^{\circ}$ and $30^{\circ}$ Elevation.

\begin{tabular}{cccc}
\hline Panel orientation & South Facing Panels & West Facing Panels & East Facing Panels \\
\hline Shade elevation & $7411 \mathrm{kWh}$ & $6611 \mathrm{kWh}$ & $6248 \mathrm{kWh}$ \\
$0^{\circ}$ & $7246 \mathrm{kWh}$ & $6424 \mathrm{kWh}$ & $6223 \mathrm{kWh}$ \\
$15^{\circ}$ & $6639 \mathrm{kWh}$ & $5891 \mathrm{kWh}$ & $5589 \mathrm{kWh}$ \\
$30^{\circ}$ & & & \\
\hline
\end{tabular}

Table 5. Maximum NPV by load profile, rate plan and solar panel orientation for $0^{\circ}, 15^{\circ}$ and $30^{\circ}$ Shade Elevations. (using an array size that maximizes the NPV for that scenario; NPV rounded to the nearest Dollar).

\begin{tabular}{|c|c|c|c|c|c|c|c|}
\hline \multirow{3}{*}{\multicolumn{2}{|c|}{$\begin{array}{c}\text { Panel orientation } \\
\text { Annual electricity consumption }\end{array}$}} & \multicolumn{2}{|c|}{ South Facing Panels } & \multicolumn{2}{|c|}{ West Facing Panels } & \multicolumn{2}{|c|}{ East Facing Panels } \\
\hline & & 741 & Nh & 741 & Nh & 741 & Nh \\
\hline & & TOU & TOU & TOU & TOU & TOU & TOU \\
\hline \multirow{4}{*}{$\begin{array}{l}\text { A. Working } \\
\text { from home }\end{array}$} & Shade elev. & & & & & & \\
\hline & $0^{\circ}$ & $\$ 8642$ & $\$ 8241$ & $\$ 8120$ & $\$ 7774$ & $\$ 6049$ & $\$ 5740$ \\
\hline & $15^{\circ}$ & $\$ 8407$ & $\$ 7934$ & $\$ 7173$ & $\$ 6682$ & $\$ 4715$ & $\$ 4273$ \\
\hline & $30^{\circ}$ & $\$ 7080$ & $\$ 6448$ & $\$ 5618$ & $\$ 4890$ & $\$ 3521$ & $\$ 3079$ \\
\hline \multirow{4}{*}{$\begin{array}{l}\text { B. Working } \\
\text { adults with no } \\
\text { school-aged } \\
\text { children }\end{array}$} & Shade elev. & & & & & & \\
\hline & $0^{\circ}$ & $\$ 8555$ & $\$ 7996$ & $\$ 7916$ & $\$ 7554$ & $\$ 5910$ & $\$ 5492$ \\
\hline & $15^{\circ}$ & $\$ 7143$ & $\$ 6591$ & $\$ 6461$ & $\$ 5867$ & $\$ 3854$ & $\$ 3256$ \\
\hline & $30^{\circ}$ & $\$ 5909$ & $\$ 5345$ & $\$ 4939$ & $\$ 4194$ & $\$ 2780$ & $\$ 2105$ \\
\hline \multirow{3}{*}{$\begin{array}{l}\text { C. WFH } \\
\text { attending } \\
\text { evening classes }\end{array}$} & $\begin{array}{c}\text { Shade elev. } \\
0^{\circ}\end{array}$ & $\$ 8404$ & $\$ 8684$ & $\$ 7613$ & $\$ 8021$ & $\$ 5900$ & $\$ 6364$ \\
\hline & $15^{\circ}$ & $\$ 6999$ & $\$ 7167$ & $\$ 6292$ & $\$ 6628$ & $\$ 4086$ & $\$ 5062$ \\
\hline & $30^{\circ}$ & $\$ 5937$ & $\$ 6069$ & $\$ 4993$ & $\$ 5200$ & $\$ 3251$ & $\$ 3709$ \\
\hline D. Working & Shade elev. & & & & & & \\
\hline adults with & $0^{\circ}$ & $\$ 8654$ & $\$ 8200$ & $\$ 7992$ & $\$ 7712$ & $\$ 5955$ & $\$ 5747$ \\
\hline school-aged & $15^{\circ}$ & $\$ 7216$ & $\$ 6851$ & $\$ 6542$ & $\$ 6147$ & $\$ 3960$ & $\$ 3583$ \\
\hline children & $30^{\circ}$ & $\$ 5989$ & $\$ 5602$ & $\$ 5107$ & $\$ 4442$ & $\$ 2887$ & $\$ 2425$ \\
\hline
\end{tabular}


directions, the solar panel array continues to be very financially viable for the customer.

\section{Conclusion}

While the load profiles used in this study surely do not capture the energy consumption patterns of all households, they are, collectively, a good representation of the energy consumption patterns of many households. Our analysis shows that homeowners who are planning on going solar and are faced with the choice of installing solar panels on the south-facing roof plane versus the west-facing roof plane should opt for the south-facing roof plane. From the load profiles examined in this paper, and given SCE's current rates, most customers are likely to save more money in the long run by going on the TOU 4-9 plan, though as we have demonstrated some load profiles will benefit more from being on the TOU 5 - 8 plan. We have also identified the ideal usage offsets for the various load profiles with different panel orientations. Finally, we examined the impact of moderate shading on the NPV of the solar panel installation and found that solar panels remain good investments even with some shading.

\section{Policy Implications}

Residential distributed energy generation using solar panels sited on residential buildings continues to be economically viable for customers of the major California utilities, while at the same time being environmentally safe and contributing to the stated goals of the state to reduce carbon emission. Distributed energy generation is superior to utility scale generation for several reasons, including the fact that the energy generation occurs at the location of energy consumption, and thus minimizes the need for grid infrastructure upgrading. Further, residential solar panels are almost always installed on rooftops which minimize environmental impact, as opposed to utility scale installations that are installed on large tracts of land which results in severe negative environmental repercussions. Residential solar panel installations generate numerous small business opportunities. Thus, policies and actions that promote the continued viability of residential solar panels is something that the California Public Utilities Commission and the state should actively pursue.

\section{Limitations \& Recommendations}

While the analysis we present is based on a few load profiles, there are surely other load profiles possible and the conclusions we present may not be valid in all cases. Further, the conclusions we arrive at are dependent on the current rates being charged by SCE and substantial changes made in the tariff could alter some of our conclusions. Finally, this paper has not examined the TOU D-Prime plan that is offered to customers with electric vehicles and battery storage installations. While Ybarra, Nyer, Broughton and Turk (2021) have done some preliminary examination of the economics of residential solar panels coupled with 
battery storage, further work remains to be done, especially with the soon to be introduced Net Metering 3.0 policies.

\section{Declaration of Interest}

The authors have no financial or material interests in any of the products, services or organizations mentioned in the body of this article.

\section{References}

Broughton, J. B., Nyer, P. U., \& Ybarra, C. E. (2021). The Economics of Battery Storage for Residential Solar Customers in Southern California. American Journal of Industrial and Business Management, 11, 924-932. https://doi.org/10.4236/ajibm.2021.118056

California Executive Order (2018). B-55-18 to Achieve Carbon Neutrality. https://www.ca.gov/archive/gov39/wp-content/uploads/2018/09/9.10.18-Executive-Ord er.pdf

California Legislative Information (2019). Assembly Bill No. 178. https://leginfo.legislature.ca.gov/faces/billTextClient.xhtml?bill id=201920200AB178

EnergySage (2017). Do Solar Panels Work in Shade. https://news.energysage.com/solar-panels-work-shade

Los Angeles Times (2020). Should California Ban Gas in New Homes? A Climate Battle Heats Up. Los Angeles Times. https://www.latimes.com/business/story/2020-12-07/should-california-ban-gas-in-new -homes-a-climate-battle-heats-up

Nyer, P. U., Broughton, J. B., \& Ybarra, C. E. (2019). The Economics of Residential Solar Panel Installations for Customers on Tiered Rate Plans. Open Journal of Business and Management, 7, 1999-2008. https://doi.org/10.4236/ojbm.2019.74137

Nyer, P. U., Ybarra, C. E., \& Broughton, J. B. (2019). The Economics of Residential Solar Panels: Comparing Tiered and Time of Use Plans. Open Journal of Business and Management, 8, 56-67. https://doi.org/10.4236/ojbm.2020.81004

Solar Energy Industries Association (2020). State Solar Spotlight-California. https://www.seia.org/sites/default/files/2020-12/California.pdf

Solar Radiation Monitoring Laboratory, University of Oregon (2019). Sun Path Chart Program. http://solardat.uoregon.edu/SunChartProgram.html

Southern California Edison (2021a). Energy Data-Reports and Compliance. https://www.sce.com/regulatory/energy-data---reports-and-compliances

Southern California Edison (2021b). Historical Prices and Rate Schedules. https://www.sce.com/regulatory/tariff-books/historical-rates

Statista (2020). Average Retail Price of Electricity to Residential Sector in the United States as of August 2020, by State.

https://www.statista.com/statistics/630090/states-with-the-average-electricity-price-for -the-residential-sector-in-the-us

Ybarra, C. E., Broughton, J. B., \& Nyer, P. U. (2021). Trends in the Installation of Residential Solar Panels in California. Low Carbon Economy, 12, 63-72.

https://doi.org/10.4236/lce.2021.122004

Ybarra, C. E., Nyer, P. U., Broughton, J. B., \& Turk, T. A. (2021). The Economics of Residential Solar and Battery Storage: Analyzing the Impact of the Joint IOU Proposal for Net Metering 3.0 in California. Low Carbon Economy, 12, 137-150.

https://doi.org/10.4236/lce.2021.124007 